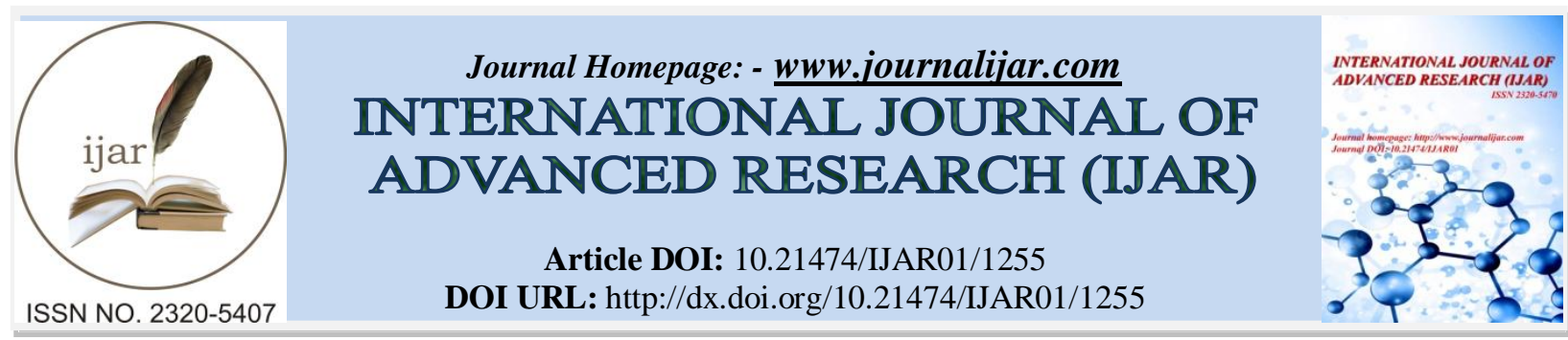

RESEARCH ARTICLE

\title{
EPIDEMIOLOGICAL AND SURVEILLANCE STUDY OF DIARRHEAGENIC E.coli AND Shigella spp IN AND AROUND TIRUCHIRAPPALLI DISTRICT, TAMIL NADU INDIA.
}

\author{
Suganya. $D^{1}$, Kanimozhi.K ${ }^{2}$, Panneerselvam. $A^{2}$ and Dhanapaul. $K^{3}$. \\ 1. Department of Microbiology, Jamal Mohamed College (Autonomous), Bharathidasan University, \\ Trichirappalli, India. \\ 2. Department of Microbiology, A.V.V.M Sri Pushpam College (Autonomous),Poondi, Thanjavur Dt, \\ Tamilnadu,India. \\ 3. Department of Microbiology, KAPViswanathan Medical College, Trichirappalli, India.
}

\section{Manuscript Info}

(1........................

Manuscript History

Received: 10 June 2016

Final Accepted: 19 July 2016

Published: August 2016

Key words:-

Diarrhea, Shigella spp, Diarrheagenic

E.coli, children, Epidemiology.

\section{Abstract}

The present study is specially targeted to determine the prevalence of various bacterial enteropathogens causing acute childhood diarrhea and to find out their respective pattern of clinical features. Very few studies have been performed in India to investigate the prevalence and characterization of Diarrheagenic E.coli in patients with diarrhea. In the few cases of acute childhood diarrhea that require antimicrobial therapy, the correct choice of the drug depends on detailed previous knowledge of local strains. In order to establish such parameters in our city, we reviewed the results of all 185 positive stool cultures of children between 0 and 15 years of age during two years. Bacterial strains had been presumptively identified by culturing in selective media and by biochemical testing and their antimicrobial susceptibility patterns were detected. Data about patients' sex and age, monthly distribution of the cases, pathogens isolated and their antimicrobial resistance patterns were recorded. Males corresponded to $55.4 \%$ of our sample, and most of our patients $(42.7 \%)$ were between one and four years of age. Shigella was the main causal agent of diarrhea in children younger than five years old. Shigella was the most frequent pathogen isolated from the stools of children between five and 15 years old. These data are useful for practitioners and they reinforce the need for continuous microbiological surveillance.

Copy Right, IJAR, 2016,. All rights reserved.

\section{Introduction:-}

Diarrhea is defined as having loose or watery stools at least three times per day or more frequently than normal for an individual. More than 1 billion cases and at least 4 million deaths per year are attributed to diarrhoea worldwide. The majority of bacterial enteric infections are transmitted through food, with the influencing risk factors varying according to the bacteria involved [1]. All over the world, severe acute bacterial gastroenteritis is caused mainly by Shigella, whereas Salmonella, E.coli (chiefly enteropathogenic E. coli, (EPEC), but also enterohemorrhagic E. coli (EHEC), enteroinvasive E. coli (EIEC) and other types such as Campylobacter and Vibrio spp. have also been shown to play a role in the epidemiology of diarrhea, especially in certain areas of the globe [2-6]. Escherichia

Corresponding Author:- Suganya.D. 
coli are the predominant facultative anaerobe of the human colonic flora. The organism typically colonizes the infant gastrointestinal tract within hours of life, and, thereafter, E. coli and the host derive mutual benefit [7]. Shigella is estimated to cause nearly half a million illnesses each year in the United States, with more than 5,400 hospitalizations and 38 deaths. Cases and controls were selected from patients attending the outpatient clinic of three different government hospitals after receiving permission from institutional ethical committee. Children were enrolled in the study if they had diarrhea characterized by the occurrence of three or more, loose watery stool or at least one bloody loose stool in a 24 hour period. Neither patients nor controls had been treated with antibiotics in the week preceding sampling. Histories were obtained through physical examination by medical doctors. Clinical symptoms, including fever, vomiting, abdominal pain, and dehydration were recorded in a standard proforma. Stool specimens from enrolled children were collected using wide-mouthed sterile plastic containers and transported immediately to the microbiology laboratory for analysis within two hours of collection.

\section{Materials and Methods:- Clinical specimens:-}

We reviewed the results of all stool cultures that presented bacterial growth that were taken from children between 0 and 15 years of age from January 2014 to July 2015 at KAPViswanathan medical college, Trichy, Tamilnadu. Data about patients' sex and age, monthly distribution of the cases, pathogens isolated and their antimicrobial resistance patterns were recorded. During that period, 196 patients had their stools cultured and 185 samples presented bacterial growth.

All bacteriological examinations were performed at the KAPViswanathan medical college hospital Trichy, Tamilnadu. Briefly, fresh feces were collected from diarrheal patients and sent to the laboratory for immediate culture. The specimens were inoculated into selenite broth and on MacConkey, Salmonella-Shigella (SS) agars. MacConkey and SS agar plates were incubated at $35^{\circ} \mathrm{C}$ for 18 to 24 hours, and selenite broth at $35^{\circ} \mathrm{C}$ for $12-18$ hours. After incubation, selenite broth was inoculated in SS agar at $35^{\circ} \mathrm{C}$ for 18 to 24 hours. Suspected colonies were inoculated in Citrate medium at $35^{\circ} \mathrm{C}$ for 18 to 24 hours for biochemical testing and presumptive identification [8]. During the period from April 2013 to July 2015, 185 stool samples from children who were from 1-15 years of age were investigated in Tiruchirappalli, Tamilnadu, India to determine the prevalence of diarrhea. This included 11 patients without diarrhea. Cases and controls were selected from patients attending the outpatient clinic of three different government hospitals after receiving permission from institutional ethical committee. Children were enrolled in the study if they had diarrhea characterized by the occurrence of three or more, loose watery stool or at least one bloody loose stool in a 24 hour period. Neither patients nor controls had been treated with antibiotics in the week preceding sampling.

\section{Age wise distribution of effected diarrheal diseases:-}

The age related distribution has shown that majority of the bacterial isolates have peak incidence between age 10years. This stage (new born to 2 years) children's must be fed up with milk i.e., breast milk. The other milk such as cow milk, lactogen easily produce diseases of diarrhea. The main reason of these children's are start to crawl so that the time the minute practical of foods like ground nut, fish bone, any non eatables, are to eat to this is to stored the stomach, it also heavily produced the diarrhea diseases.

\section{Results and Discussion:-}

In the present study, the diarrheal diseases highly affected in new born baby, children around 5 years. It's become to unhygienic food and non proper preparation. Above 5 years peoples also are affected Diarrheal diseases. It's come to knew they affected of hotel food, species food and non veg. But they are minimum amount of affected of Diarrheal diseases. Given the importance of a careful characterization of the local epidemiology of diarrhea to guide specific antimicrobial therapy, we reviewed the results of 185 stool cultures from children aged 0 to 15 years old in which enteropathogens were detected. More than half of the cases were caused by Shigella spp., reinforcing the importance of this pathogen in the epidemiology of bacterial childhood diarrhea in developing countries [9]. Indeed, most patients with shigellosis require immediate hospitalization. The prevalence and other epidemiological features of these pathogens as causative agents of diarrhea vary from region to region. This variation is also seen between and within countries in the same geographical area. During the two-year period 185 samples presented bacterial growth. Epidemiologic investigations have implicated contaminated food and water as the most common vehicles for the diarrheal infection [10]. Shigella was the most frequent pathogen isolated from the stools of children between five and nine years-old and between 10 and 15 years old [11]. (Table1). 
Table 1:- Distribution of the pathogens in diarrheal stools according to patients' age.

\begin{tabular}{|l|l|l|l|}
\hline Age Distribution & Shigella spp & E.coli & Total \\
\hline <1year & 24 & 14 & 38 \\
\hline 1-4year & 16 & 28 & 44 \\
\hline 5-9 year & 22 & 26 & 48 \\
\hline $10-15$ year & 32 & 23 & 55 \\
\hline Total & 94 & 91 & 185 \\
\hline
\end{tabular}

Figure 1:- Distribution of patients with diarrhea according to age range.

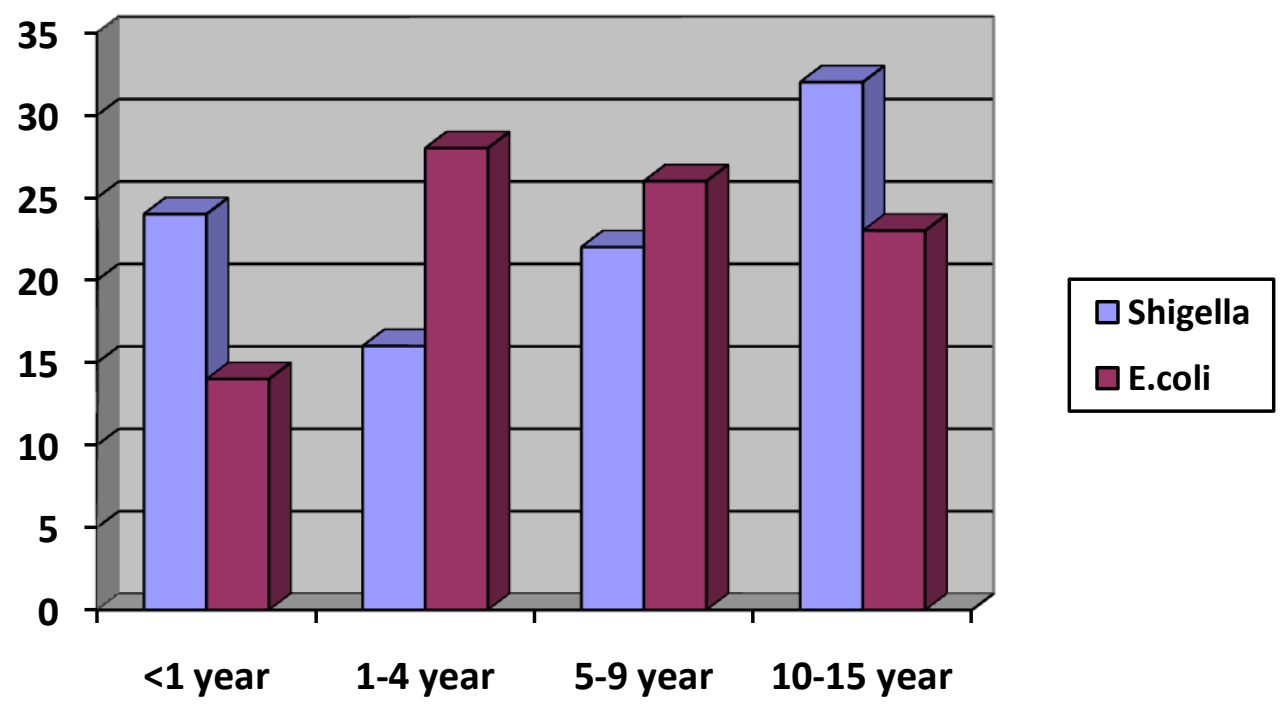

\section{References:-}

1. Walker CL, and Black RE. 2010. Diarrhoea morbidity and mortality in older children, adolescents, and adults.Epidemiol Infect. ; 138:1215-26.

2. World Health Organization. Diarrhoeal disease due to Shigella disease. 1998. In: Vaccines, immunization and biologicals. Geneva: World Health Organization, 1-5.

3. Shears P. 1996. Shigella infections. Ann Trop Med Parasitol 90:105-14.

4. Tjaniadi P., Lesmana M., and Subekti D.2003. Antimicrobial resistance of bacterial pathogens associated with diarrheal patients in Indonesia. Am J Trop Med Hyg 68:666-70.

5. Niemogha M.T., Alabe S.A., and Uzoma K.L. 1995. The incidence of Salmonella, Shigella and other enteric bacterial pathogens in stool specimens of diarrhoea patients. Niger Med J; 28:70-4.

6. Wasfy M.O., Oyofo B.A., and David J.C. 2000. Isolation and antibiotic susceptibility of Salmonella, Shigella andCampylobacter from acute enteric infections in Egypt. J Health Popul Nutr; 18:338.

7. Drasar B S, and Hill M J. 1974. Human intestinal flora. London, United Kingdom: Academic Press, Ltd.; pp. 36-43.

8. National Committee for Clinical Laboratory Standards. 1995. Performance standards for antimicrobial testing: sixth international supplement. Wayne PA: National Committee for Clinical Laboratory Standards, (NCCLS document no. MI00-S6).

9. Taylor D N, Echeverria P, Sethabutr O, Pitarangi C, Leksomboon U, Blacklow N R, Rowe B, Gross R, and Cross J. 1988. Clinical and microbiologic features of Shigella and enteroinvasive Escherichia coli infections detected by DNA hybridization. J Clin Microbiol. ; 26:1362-1366.

10. Black R E, Brown K H, Becker S, Abdul Alim A R M, and Merson M H. 1982. Contamination of weaning foods and transmission of enterotoxigenic Escherichia coli diarrhoea in children in rural Bangladesh. Trans $R$ Soc Trop Med Hyg. 76:259-264.

11. Ketyi I. 1989. Epidemiology of the enteroinvasive Escherichia coli. Observations in Hungary. J Hyg Epidemiol Microbiol Immunol. 33:261-267 